\title{
Enhancing Employability Skills of Woodwork Technology Education Students through Project Based Learning at Colleges of Education (Technical) in Nigeria
}

\author{
Muhammad Umar Isa*, Yusri Bin Kamin, Yahya Ibn Salihu, Halliru Shuaibu, \\ Abdullahi Musa Cledumas \\ Department of Technical and Engineering Education, School of Education, Faculty of Social Sciences and Humanities, Universiti \\ Teknologi Malaysia, Johor, Malaysia
}

Received March 15, 2019; Revised July 15, 2020; Accepted July 29, 2020

\section{Cite This Paper in the following Citation Styles}

(a): [1] Muhammad Umar Isa, Yusri Bin Kamin, Yahya Ibn Salihu, Halliru Shuaibu, Abdullahi Musa Cledumas , "Enhancing Employability Skills of Woodwork Technology Education Students Through Project Based Learning at Colleges of Education (Technical) in Nigeria," Universal Journal of Educational Research, Vol. 8, No. 9A, pp. 31 - 40, 2020. DOI: 10.13189/ujer.2020.082005.

(b): Muhammad Umar Isa, Yusri Bin Kamin, Yahya Ibn Salihu, Halliru Shuaibu, Abdullahi Musa Cledumas (2020). Enhancing Employability Skills of Woodwork Technology Education Students Through Project Based Learning at Colleges of Education (Technical) in Nigeria. Universal Journal of Educational Research, 8(9A), 31 - 40. DOI: 10.13189/ujer.2020.082005.

Copyright $\bigcirc 2020$ by authors, all rights reserved. Authors agree that this article remains permanently open access under the terms of the Creative Commons Attribution License 4.0 International License

\begin{abstract}
Employability skills are essential skills needed in today's work place for effective employment sustainability. However, most graduates of woodwork technology at colleges of education (Technical) in Nigeria lacked employability skills and as such cannot be employed in the wood industry. Therefore, this paper seeks to determine effective strategies for enhancing woodwork technology education student's employability skills through project-based learning (PoBL) at COET in Nigeria. Three research questions and four hypotheses were posed for the study. The study population comprised 67 respondents for the quantitative part and 7 participants for the qualitative part involving WTE lecturers at COET in north western Nigeria. Data for the study were collected through structured questionnaire and interview protocol, and analyse using SPSS version 24 to process the frequency, percentage, mean, standard deviation and t-test for the questionnaire, while NVIVO 12 was used to transcribe the interview. Findings from the study revealed that most elements of employability skills are not embedded into the curriculum of WTE. The findings also revealed that through effective implementation of PoBL, engaging students in activities that could enhance their creativity, critical thinking, communication skills and
\end{abstract}

application of ICT in WTE teaching and learning, WTE student's employability skills will be enhanced.

Keywords Employability Skills, Project Based Learning, Woodwork Technology Education, Colleges of Education Technical

\section{Introduction}

Employability skills are a set of skills needed for success in the $21^{\text {st }}$ century world of work for employment sustainability. As technology changes so also the employment requirements changes, and for this reason graduates of specific fields need to be equipped with the skills that suit $21^{\text {st }}$ century employment requirements (Noordin, 2014). Today's world of work demands employees not only with technical skills but also with employability skills (Ismail \& Mohammed, 2015). However, it has been observed that in Nigeria, graduates of WTE at COET lacked employability skills (Udofia, Ekpo, Nsa, \& Akpan, 2012). A situation that has rendered many WTE graduates unemployed in Nigeria, thus lead to many 
social vices like thuggery and kidnapping in the country. Further, curtailing WTE graduates unemployment in Nigeria requires a functional curriculum and instructional processes that aid transmission of employability skills which aligns with $21^{\text {st }}$ century work skill demand. In this regard, restructuring the curriculum of WTE at Nigerian tertiary institutions (COET) to involve employability skills becomes desirable for enhancement of students' skills.

Furthermore, incorporating employability skills in a course curriculum like WTE requires a $21^{\text {st }}$ century instructional approach that can aid effective skills acquisition. On this basis, utilising project based learning (PoBL) could facilitate in acquiring effective employability skills. According to Bender (2012) PoBL is an instructional learning model used in the $21^{\text {st }}$ century for engaging students in acquiring skills necessary in the modern work place. Additionally, Du and Kolmos (2006) described PoBL as an instructional learning that equips students not only with scientific knowledge or technical skills, but also with employability skills in order to be adaptable to $21^{\text {st }}$ century work place. This implies that PoBL is a veritable instructional approach that is capable of transmitting skills needed for successful employment in the $21^{\text {st }}$ century work environment. At this premise, it deems necessary to restructure the curriculum of WTE at COET to focus more on employability skills acquisition through the utilisation of PoBL instructional approach.

\subsection{Problem Statement}

Employability skills have been discovered to be essential indices for successful employment in the $21^{\text {st }}$ century. This has led to employers to seek for employees who possess employability skills. Nowadays, woodwork technology education (WTE) graduates produced from COET in Nigeria do not possess and meet the requirements of the work place due to their lack of employability skills such as wood design, development, construction, including communication, collaboration, problem solving and leadership skills. For this reason, WTE graduates are not employed by the industries. However, the non-possession of employability skills by WTE graduates could be connected to the curriculum and instructional processes in WTE at COET in Nigeria. In this regard project based learning seems an appropriate instructional model for enhancing student's employability skills. Therefore, there is a need to restructure WTE curriculum at COET in Nigeria to include employability skills and PoBL in the instructional delivery of WTE for students' skill enhancement in order to fit in the $21^{\text {st }}$ century work place.

\subsection{Purpose of the Study}

The main aim of this study is to determine effective approaches for enhancing WTE students' employability skills through PoBL. Specifically, the study sought to:

a). Identify employability skill elements in WTE curriculum at COET in Nigeria

b). Identify instructional approaches adopted in acquiring WTE skills at COET in Nigeria.

c). Determine effective strategies for enhancing students' employability skills in WTE through PoBL at COET in Nigeria.

\subsection{Research Questions}

i). What elements of employability skills are incorporated in WTE curriculum at COET in Nigeria?

ii). What instructional approaches are adopted in acquiring WTE skills at COET in Nigeria?

iii). What strategies could be employed in enhancing WTE students' employability skills through PoBL at COET in Nigeria?

\subsection{Hypothesis}

The following null hypothesis were tested at 0.05 level of significance:

Ho1 There is no significant difference between the mean responses of the respondents on elements of employability skills incorporated in WTE curriculum at COET in Nigeria

Ho2 There is no significant difference between the mean responses of the respondents on instructional approaches adopted in acquiring WTE skills at COET in Nigeria.

Ho3 There is no significant difference between the mean responses of the respondents on strategies that can be employed in enhancing WTE students' employability skills at COET in Nigeria.

\section{Employability Skills}

Employability skills are a set of skills or attributes that employers specify for employees in order to be employed. Lowden, Hall, Elliot, and Lewin (2011) described employability as transferable skills needed by individuals to make them employable. Similarly, Wickramasinghe and Perera (2010) perceived employability skills as certain attributes of skills and personal characteristics that make graduates more likely to gain employment and to be successful in their desired job that benefits them, the workforce, the community and the economy. Further, employability skills have been called with different names such as soft skills, professional skills, key competencies, generic skills among others (Colwell, 2010; Nasir, Ali, Noordin, \& Nordin, 2011). But in spite different names they are called they are fundamentally the same (United Nations Educational \& Organization, 2010). There are three categories of employability skills such as core skills, 
generic skills and personal attributes (Ismail \& Mohammed, 2015).

\subsection{Woodwork Technology Education at Colleges of Education (Technical) in Nigeria}

Colleges of education (Technical) are the third categories of tertiary institutions in Nigeria that offer technical and vocational education. Specifically, COET are tertiary institutions in Nigeria concerned with imparting TVET knowledge, skills and attitudes to students so as to be equipped with scientific, technological and pedagogical knowledge and skills for effective participation in the work place (Attaochu, 2013). Accordingly, (Aliyu, 2016) posits that COET are distinct from other conventional COE because they pay much attention to technological skills as well as scientific knowledge and pedagogical skills for successful employment in the industry and teaching TVET at primary and secondary schools as well. Further, woodwork technology education is recognised as one of the TVET program designed to train students in acquiring the necessary technological skills and scientific knowledge for successful employment(Aliyu, 2016). WTE is therefore perceived as a program in COET which necessitates the acquisition of cognitive and psychomotor skill in furniture making, cabinet making, upholstery construction, carpentry, wood machining and general woodworking (Muhammad, 2016). To this end WTE as a course in COET affords students the opportunity to acquire skills and competencies in various areas of specialisation in woodworking in order to be employable.

\subsection{Project Based Learning}

PoBL has been identified as an effective approach to learning essential skills needed for successful employment (Ravitz, Hixson, English, \& Mergendoller, 2012). Accordingly, Johnson and Ulseth (2014) described PoBL as a learning approach that affords students with the ability to learn skills employers need from employees at the work place. Essentially PoBL develops student's skills for successful participation in the $21^{\text {st }}$ century work environment. This explains why PoBL is seen as a tool for developing employability skills in learners since it provides learners with the ability to learn interpersonal, technical, communication and management skills to cope in the job after school (Tam \& Trzmiel, 2018).

\section{Methodology}

The design and procedures used in carrying out this study were highlighted under the following sub headings:

\subsection{Research Design}

The methodology employed for this research is a mixed method approach which combines quantitative and qualitative research in a study, starting with a quantitative method and followed up with a qualitative.

\subsection{Study Area}

The study was conducted in the north western part of Nigeria and comprised 2 COET offering woodwork technology education, that is FCET Bichi, and FCET Gusau.

\subsection{Population and Sampling}

The population for the study were 67 WTE lecturers purposively selected from the 2 FCET. 7 were used for qualitative aspect and 67 for the quantitative part. The reason for the selection of participants in a purposive sampling is based on their knowledge or experiences in providing the information that needs to be known for a study (Tongco, 2007). Furthermore, the criteria used in selecting participants for the qualitative part is based on experience. In this regard, WTE lecturers with at least master degree and above with 15 years working experience and above were used as participants for the qualitative aspect of the study.

\subsection{Instrumentation}

Two sets of instruments were used for data collection for the study. A structured questionnaire was used for the quantitative part of the study and analyse using SPSS version 24 to process the frequency, percentage, mean, standard deviation and t-test for testing the null hypotheses at 0.05 level of significance which were presented in tables. Items with mean values of 3.50 and above were considered agreed while items with mean values below 3.50 were considered disagree. Similarly, the null hypothesis of items with P-values of 0.05 or greater than were considered accepted, while items with P-values less than 0.05 were considered rejected. Further, interview protocol was used for the qualitative part and analysed through thematic content analysis with the help of Nvivo version 12 and presented in a table and chat.

\section{Findings}

\subsection{Quantitative Findings}

Findings from the quantitative results are presented in tables 1-3 and charts according to the research questions posed and hypothesis formulated for the study.

RQ1. What elements of employability skills are incorporated into WTE curriculum at COET in Nigeria? 
Table 1. Frequency, Percentage, Mean Responses and P-values on Elements of Employability skills incorporated in WTE curriculum

\begin{tabular}{|c|c|c|c|c|c|c|c|c|c|}
\hline \multirow[t]{2}{*}{ No } & Items & $\begin{array}{c}\mathrm{SD} \\
\mathrm{f} /(\%)\end{array}$ & $\begin{array}{c}D \\
f /(\%) \\
\end{array}$ & $\begin{array}{c}\text { FA } \\
\mathrm{f} /(\%)\end{array}$ & $\begin{array}{c}A \\
f /(\%)\end{array}$ & $\begin{array}{c}\mathrm{SA} \\
\mathrm{f} /(\%)\end{array}$ & Mean & SD & P.V \\
\hline & Generic Skills & \multirow[b]{2}{*}{$\begin{array}{c}22 \\
(32.8)\end{array}$} & \multirow[b]{2}{*}{$\begin{array}{c}20 \\
(29.9)\end{array}$} & \multirow[b]{2}{*}{$\begin{array}{c}15 \\
(22.4)\end{array}$} & \multirow[b]{2}{*}{$\begin{array}{c}6 \\
(9.0)\end{array}$} & \multirow[b]{2}{*}{$\begin{array}{c}4 \\
(6.0)\end{array}$} & \multirow[b]{2}{*}{2.25} & \multirow[b]{2}{*}{1.18} & \multirow[b]{2}{*}{.66} \\
\hline 1 & $\begin{array}{l}\text { Problem solving and adaptability } \\
\text { skills }\end{array}$ & & & & & & & & \\
\hline 2 & Professional Competency & $\begin{array}{c}11 \\
(16.4)\end{array}$ & $\begin{array}{c}17 \\
(25.4)\end{array}$ & $\begin{array}{c}16 \\
(23.9) \\
\end{array}$ & $\begin{array}{c}13 \\
(19.4)\end{array}$ & $\begin{array}{c}10 \\
(14.9)\end{array}$ & 2.91 & 1.31 & .51 \\
\hline 3 & Group working skills & $\begin{array}{c}17 \\
(25.4)\end{array}$ & $\begin{array}{c}14 \\
(20.9)\end{array}$ & $\begin{array}{c}12 \\
(17.9)\end{array}$ & $\begin{array}{c}8 \\
(11.9)\end{array}$ & $\begin{array}{c}16 \\
(23.9)\end{array}$ & 2.88 & 1.52 & .38 \\
\hline 4 & Interpersonal Skills & $\begin{array}{c}22 \\
(32.8) \\
\end{array}$ & $\begin{array}{c}19 \\
(28.4)\end{array}$ & $\begin{array}{c}10 \\
(14.9)\end{array}$ & $\begin{array}{c}10 \\
(14.9)\end{array}$ & $\begin{array}{c}6 \\
(9.0) \\
\end{array}$ & 2.38 & 1.32 & .08 \\
\hline 5 & Creativity and innovation skills & $\begin{array}{c}16 \\
(23.9) \\
\end{array}$ & $\begin{array}{c}22 \\
(32.8) \\
\end{array}$ & $\begin{array}{c}14 \\
(20.9) \\
\end{array}$ & $\begin{array}{c}6 \\
(9.0) \\
\end{array}$ & $\begin{array}{c}9 \\
(13.4) \\
\end{array}$ & 2.55 & 1.31 & .92 \\
\hline 6 & $\begin{array}{c}\text { Information technology and } \\
\text { computer skills }\end{array}$ & $\begin{array}{c}21 \\
(31.3) \\
\end{array}$ & $\begin{array}{c}20 \\
(29.9) \\
\end{array}$ & $\begin{array}{c}8 \\
(11.9) \\
\end{array}$ & $\begin{array}{c}12 \\
(17.9)\end{array}$ & $\begin{array}{c}6 \\
(9.0) \\
\end{array}$ & 2.43 & 1.33 & .98 \\
\hline 7 & Leadership skills & $\begin{array}{c}13 \\
(19.4) \\
\end{array}$ & $22(32.8)$ & $\begin{array}{c}12 \\
(17.9) \\
\end{array}$ & $\begin{array}{c}8 \\
(11.9) \\
\end{array}$ & $\begin{array}{c}12 \\
(17.9) \\
\end{array}$ & 2.76 & 1.38 & .40 \\
\hline 8 & Communication skills & $\begin{array}{c}13 \\
(19.4)\end{array}$ & $\begin{array}{c}12 \\
(17.9)\end{array}$ & $\begin{array}{c}15 \\
(22.4)\end{array}$ & $\begin{array}{c}16 \\
(23.9)\end{array}$ & $\begin{array}{c}11 \\
(16.4)\end{array}$ & 3.00 & 1.37 & .37 \\
\hline 9 & Time management skills & $\begin{array}{c}23 \\
(34.3) \\
\end{array}$ & $\begin{array}{c}18 \\
(26.9)\end{array}$ & $\begin{array}{c}12 \\
(17.9)\end{array}$ & $\begin{array}{c}8 \\
(11.9) \\
\end{array}$ & $\begin{array}{c}6 \\
(9.0) \\
\end{array}$ & 2.34 & 1.30 & .38 \\
\hline \multirow[t]{2}{*}{10} & Critical thinking skills & $\begin{array}{c}21 \\
(31.3) \\
\end{array}$ & $\begin{array}{c}23 \\
(34.3) \\
\end{array}$ & $\begin{array}{c}16 \\
(23.9) \\
\end{array}$ & $\begin{array}{c}2 \\
(3.0) \\
\end{array}$ & $\begin{array}{c}5 \\
(7.5) \\
\end{array}$ & 2.20 & 1.14 & .29 \\
\hline & Core Skills & \multirow[b]{2}{*}{$\begin{array}{c}12 \\
(17.9) \\
\end{array}$} & \multirow[b]{2}{*}{$\begin{array}{c}17 \\
(25.4)\end{array}$} & \multirow[b]{2}{*}{$\begin{array}{c}13 \\
(19.4)\end{array}$} & \multirow[b]{2}{*}{$\begin{array}{c}15 \\
(22.4)\end{array}$} & \multirow[b]{2}{*}{$\begin{array}{c}10 \\
(14.9)\end{array}$} & \multirow[b]{2}{*}{2.91} & \multirow[b]{2}{*}{1.34} & \multirow[b]{2}{*}{.92} \\
\hline 11 & $\begin{array}{c}\text { Knowledge of science and } \\
\text { technology education principles }\end{array}$ & & & & & & & & \\
\hline 12 & $\begin{array}{l}\text { Woodwork technology education } \\
\text { practice }\end{array}$ & $\begin{array}{c}3 \\
(4.5)\end{array}$ & $\begin{array}{c}2 \\
(3.0)\end{array}$ & $\begin{array}{c}1 \\
(1.5)\end{array}$ & $\begin{array}{c}31 \\
(46.3)\end{array}$ & $\begin{array}{c}30 \\
(44.8)\end{array}$ & 4.23 & .970 & .27 \\
\hline 13 & $\begin{array}{l}\text { Use and application of wood modern } \\
\text { machine and tool operation }\end{array}$ & $\begin{array}{c}8 \\
(11.9) \\
\end{array}$ & $\begin{array}{c}12 \\
(17.9)\end{array}$ & $\begin{array}{c}10 \\
(14.9)\end{array}$ & $\begin{array}{c}12 \\
(17.9)\end{array}$ & $\begin{array}{c}25 \\
(37.3) \\
\end{array}$ & 3.50 & 1.44 & .22 \\
\hline 14 & $\begin{array}{c}\text { Competency in wood item } \\
\text { production }\end{array}$ & $\begin{array}{c}7 \\
(10.4) \\
\end{array}$ & $\begin{array}{c}10 \\
(14.9)\end{array}$ & $\begin{array}{c}12 \\
(17.9)\end{array}$ & $\begin{array}{c}18 \\
(26.9) \\
\end{array}$ & $\begin{array}{c}20 \\
(29.9) \\
\end{array}$ & 3.50 & 1.34 & .04 \\
\hline \multirow[t]{2}{*}{15} & $\begin{array}{c}\text { Repair and refurbishing wooden } \\
\text { items and equipment }\end{array}$ & $\begin{array}{c}6 \\
(9.0) \\
\end{array}$ & $\begin{array}{c}7 \\
(10.4) \\
\end{array}$ & $\begin{array}{c}6 \\
(9.0) \\
\end{array}$ & $\begin{array}{c}20 \\
(29.9) \\
\end{array}$ & $\begin{array}{c}28 \\
(41.8) \\
\end{array}$ & 3.85 & 1.35 & .004 \\
\hline & Personal Attributes & \multirow[b]{2}{*}{$\begin{array}{c}18 \\
(26.9) \\
\end{array}$} & \multirow[b]{2}{*}{$\begin{array}{c}21 \\
(31.3) \\
\end{array}$} & \multirow[b]{2}{*}{$\begin{array}{c}12 \\
(17.9)\end{array}$} & \multirow[b]{2}{*}{$\begin{array}{c}7 \\
(10.4) \\
\end{array}$} & \multirow[b]{2}{*}{$\begin{array}{c}9 \\
(13.4)\end{array}$} & \multirow[b]{2}{*}{2.52} & \multirow[b]{2}{*}{1.35} & \multirow[b]{2}{*}{.05} \\
\hline 16 & $\begin{array}{c}\text { Social, cultural, global and } \\
\text { environmental responsibility skills }\end{array}$ & & & & & & & & \\
\hline 17 & Knowledge about competency issues & $\begin{array}{c}13 \\
(19.4)\end{array}$ & $\begin{array}{c}18 \\
(26.9)\end{array}$ & $\begin{array}{c}15 \\
(22.4) \\
\end{array}$ & $\begin{array}{c}9 \\
(13.4)\end{array}$ & $\begin{array}{c}12 \\
(17.9)\end{array}$ & 2.83 & 1.37 & .77 \\
\hline
\end{tabular}

Data presented in table 1 revealed 14 items had mean values that ranged from 2.25 to 3.00 which shows that the mean values are below the cut-off point of 3.50 indicating that the respondents disagreed to 14 out of the 17 elements of employability skill as been incorporated in WTE curriculum. However, items 13-16 had their mean values ranged from 3.50 and above which are within and above the cut-off point of 3.50 indicating that the respondents agreed to 4 out of the 17 elements of employability skills incorporated in WTE curriculum. The table also revealed that standard deviation of the 17 items ranged from 1.00-1.52 indicating that the respondents mean responses are not far from one another. Furthermore, the P-values of the items in table 1 revealed that 15 out of the 17 items had their P-values equal and exceeded 0.05 level of significance indicating that no significant difference existed between the mean responses of the respondents on elements of employability skills incorporated in WTE curriculum. Similarly, items 14 and 15 had their P-values below 0.05 level of significance indicating that a significant difference existed between the mean responses of the respondents on elements of employability skills incorporated in WTE curriculum. Therefore, the null hypotheses of no significant difference were accepted on 15 items on elements of employability skills and rejected on 2 items. 
Table 2. Frequency, Percentage, Mean responses and P-values on Instructional approaches adopted in acquiring WTE skills

\begin{tabular}{|c|c|c|c|c|c|c|c|c|c|}
\hline No & Items & $\begin{array}{l}\text { SD } \\
\mathrm{f} /(\%)\end{array}$ & $\begin{array}{c}D \\
f /(\%)\end{array}$ & $\begin{array}{c}\text { FA } \\
f /(\%)\end{array}$ & $\begin{array}{c}A \\
f /(\%)\end{array}$ & $\begin{array}{c}\mathrm{SA} \\
\mathrm{f} /(\%)\end{array}$ & Mean & SD & P.V \\
\hline 1 & $\begin{array}{l}\text { Project Method is adopted in } \\
\text { acquiring WTE skills }\end{array}$ & $\begin{array}{c}8 \\
(11.9) \\
\end{array}$ & $\begin{array}{c}4 \\
(6.0)\end{array}$ & $\begin{array}{c}2 \\
(3.0)\end{array}$ & $\begin{array}{c}24 \\
(35.8)\end{array}$ & $\begin{array}{c}29 \\
(43.3)\end{array}$ & 3.92 & 1.34 & .57 \\
\hline 2 & $\begin{array}{l}\text { Problem based learning is adopted } \\
\text { in acquiring WTE skills }\end{array}$ & $\begin{array}{c}19 \\
(28.4) \\
\end{array}$ & $\begin{array}{c}18 \\
(26.9) \\
\end{array}$ & $\begin{array}{c}20 \\
(29.9)\end{array}$ & $\begin{array}{c}4 \\
(6.0)\end{array}$ & $\begin{array}{c}6 \\
(9.0) \\
\end{array}$ & 2.40 & 1.21 & .45 \\
\hline 3 & $\begin{array}{l}\text { Inquiry based Learning is adopted } \\
\text { in acquiring WTE skills }\end{array}$ & $\begin{array}{c}21 \\
(31.3)\end{array}$ & $\begin{array}{c}16 \\
(23.9)\end{array}$ & $\begin{array}{c}15 \\
(22.4)\end{array}$ & $\begin{array}{c}7 \\
(10.4) \\
\end{array}$ & $\begin{array}{c}8 \\
(11.9)\end{array}$ & 2.47 & 1.35 & .63 \\
\hline 4 & $\begin{array}{l}\text { Lecture method is adopted in } \\
\text { acquiring WTE skills }\end{array}$ & $\begin{array}{c}2 \\
(3.0)\end{array}$ & $\begin{array}{c}3 \\
(4.5) \\
\end{array}$ & $\begin{array}{c}8 \\
(11.9) \\
\end{array}$ & $\begin{array}{c}24 \\
(35.8) \\
\end{array}$ & $\begin{array}{c}30 \\
(44.8) \\
\end{array}$ & 4.14 & 1.00 & .96 \\
\hline 5 & $\begin{array}{l}\text { Demonstration method is adopted } \\
\text { in acquiring WTE skills }\end{array}$ & $\begin{array}{c}6 \\
(9.0) \\
\end{array}$ & $\begin{array}{c}7 \\
(10.4) \\
\end{array}$ & $\begin{array}{c}5 \\
(7.5)\end{array}$ & $\begin{array}{c}22 \\
(32.8) \\
\end{array}$ & $\begin{array}{c}27 \\
(40.3) \\
\end{array}$ & 3.85 & 1.30 & .43 \\
\hline 6 & $\begin{array}{l}\text { Challenge based learning is adopted } \\
\text { in Acquiring WTE skills }\end{array}$ & $\begin{array}{c}28 \\
(41.8) \\
\end{array}$ & $\begin{array}{c}25 \\
(37.3) \\
\end{array}$ & $\begin{array}{c}11 \\
(16.4) \\
\end{array}$ & $\begin{array}{c}1 \\
(1.5) \\
\end{array}$ & $\begin{array}{c}2 \\
(3.0) \\
\end{array}$ & 1.87 & .951 & .56 \\
\hline 7 & $\begin{array}{l}\text { Assignment method is adopted in } \\
\text { acquiring WTE skills }\end{array}$ & $\begin{array}{c}7 \\
(10.4) \\
\end{array}$ & $\begin{array}{c}9 \\
(13.4) \\
\end{array}$ & $\begin{array}{c}13 \\
(19.4) \\
\end{array}$ & $\begin{array}{c}18 \\
(26.9) \\
\end{array}$ & $\begin{array}{c}20 \\
(29.9) \\
\end{array}$ & 3.52 & 1.32 & .62 \\
\hline 8 & $\begin{array}{l}\text { Discussion method is adopted in } \\
\text { acquiring WTE skills }\end{array}$ & $\begin{array}{c}15 \\
(22.4)\end{array}$ & $\begin{array}{c}8 \\
(11.9) \\
\end{array}$ & $\begin{array}{c}18 \\
(26.9)\end{array}$ & $\begin{array}{c}12 \\
(17.9)\end{array}$ & $\begin{array}{c}14 \\
(20.9)\end{array}$ & 3.02 & 1.43 & .62 \\
\hline 9 & $\begin{array}{l}\text { Simulation approach is adopted in } \\
\text { acquiring WTE skills }\end{array}$ & $\begin{array}{c}15 \\
(22.4)\end{array}$ & $\begin{array}{c}8 \\
(11.9)\end{array}$ & $\begin{array}{c}18 \\
(26.9)\end{array}$ & $\begin{array}{c}12 \\
(17.9)\end{array}$ & $\begin{array}{c}14 \\
(20.9)\end{array}$ & 2.02 & 1.43 & .88 \\
\hline 10 & $\begin{array}{l}\text { Presentation approach is adopted in } \\
\text { acquiring WTE skills }\end{array}$ & $\begin{array}{c}17 \\
(25.4)\end{array}$ & $\begin{array}{c}19 \\
(28.4)\end{array}$ & $\begin{array}{c}14 \\
(20.9)\end{array}$ & $\begin{array}{c}13 \\
(19.4)\end{array}$ & $\begin{array}{c}4 \\
(6.0)\end{array}$ & 2.52 & 1.23 & .60 \\
\hline 11 & $\begin{array}{l}\text { Activity based learning is adopted } \\
\text { in acquiring WTE skills }\end{array}$ & $\begin{array}{c}20 \\
(29.9) \\
\end{array}$ & $\begin{array}{c}17 \\
(25.4)\end{array}$ & $\begin{array}{c}12 \\
(17.9)\end{array}$ & $\begin{array}{c}7 \\
(10.4) \\
\end{array}$ & $\begin{array}{c}11 \\
(16.4)\end{array}$ & 2.58 & 1.43 & .36 \\
\hline
\end{tabular}

RQ 2. What instructional approaches are adopted in acquiring WTE skills at COET in Nigeria?

Result presented in table 2 revealed that 7 out of the 11 items had their mean values ranged between 1.30 to 3.02 which shows that the mean values are below the cut-off point of 3.50 indicating that the respondents disagreed on 7 out of the 11 instructional approaches adopted in acquiring WTE skills. Equally, items 1, 4, 5 and 7 had mean values ranging between 3.52 to 4.14 which are above the cut-off point of 3.50, thus indicating that the respondents agreed to 4 out of the 11 instructional approaches adopted in acquiring WTE skills. Additionally, result in table 1 revealed that the standard deviation of the 11 items ranges between 0.95 to 1.43 indicating that the respondents are close to one another in their opinion. Table 2 also revealed that all the items had their P-values above 0.05 level of significance indicating that there is no significant difference in the mean responses of the respondents on instructional approaches adopted in acquiring WTE skills. Therefore, the null hypotheses of no significant difference are upheld for all the 11instructional approaches adopted in acquiring WTE skills. 
Table 3. Frequency, percentage, Mean responses and P-value on strategies to be employ for enhancing WTE students' employability skills through PoBL

\begin{tabular}{|c|c|c|c|c|c|c|c|c|c|}
\hline No & Item & $\begin{array}{l}S D \\
f /(\%)\end{array}$ & $\begin{array}{c}D \\
f /(\%)\end{array}$ & $\begin{array}{c}\text { FA } \\
f /(\%)\end{array}$ & $\begin{array}{c}A \\
f /(\%)\end{array}$ & $\begin{array}{c}S A \\
f /(\%)\end{array}$ & Mean & SD & P.V \\
\hline 1 & $\begin{array}{l}\text { Restructure WTE curriculum to } \\
\text { incorporate project based learning }\end{array}$ & $\begin{array}{c}4 \\
(6.0) \\
\end{array}$ & $\begin{array}{c}4 \\
(6.0) \\
\end{array}$ & $\begin{array}{c}12 \\
(17.9)\end{array}$ & $\begin{array}{c}25 \\
(37.3) \\
\end{array}$ & $\begin{array}{c}22 \\
(32.8) \\
\end{array}$ & 3.85 & 1.13 & .20 \\
\hline 2 & $\begin{array}{c}\text { WTE curriculum should emphasis } \\
\text { industry skill needs }\end{array}$ & $\begin{array}{c}4 \\
(6) \\
\end{array}$ & $\begin{array}{c}7 \\
(10.4) \\
\end{array}$ & $\begin{array}{c}16 \\
(23.9 \\
\end{array}$ & $\begin{array}{c}21 \\
(31.3) \\
\end{array}$ & $\begin{array}{c}19 \\
(28.4) \\
\end{array}$ & 3.65 & 1.17 & .77 \\
\hline 3 & $\begin{array}{c}\text { WTE curriculum should emphasise } \\
\text { more on employability skill } \\
\text { acquisition }\end{array}$ & $\begin{array}{c}3 \\
(4.5)\end{array}$ & $\begin{array}{c}5 \\
(7.5)\end{array}$ & $\begin{array}{c}15 \\
(22.4)\end{array}$ & $\begin{array}{c}21 \\
(31.3)\end{array}$ & $\begin{array}{c}23 \\
(34.3)\end{array}$ & 3.83 & 1.12 & .89 \\
\hline 4 & $\begin{array}{c}\text { Engagement of WTE students in } \\
\text { constructive investigations }\end{array}$ & $\begin{array}{c}7 \\
(10.4) \\
\end{array}$ & $\begin{array}{c}3 \\
(4.5) \\
\end{array}$ & $\begin{array}{c}13 \\
(19.4) \\
\end{array}$ & $\begin{array}{c}26 \\
(38.8)\end{array}$ & $\begin{array}{c}18 \\
(26.9)\end{array}$ & 3.67 & 1.22 & .66 \\
\hline 5 & $\begin{array}{l}\text { Adoption of project based learning } \\
\text { in WTE instructions }\end{array}$ & $\begin{array}{c}0 \\
(0)\end{array}$ & $\begin{array}{c}5 \\
(7.5)\end{array}$ & $\begin{array}{c}12 \\
(17.9)\end{array}$ & $\begin{array}{c}28 \\
(41.8) \\
\end{array}$ & $\begin{array}{c}22 \\
(32.8)\end{array}$ & 4.0 & .904 & .58 \\
\hline 6 & $\begin{array}{l}\text { Incorporate use and application of } \\
\text { information communication } \\
\text { technology in WTE curriculum }\end{array}$ & $\begin{array}{c}0 \\
(0)\end{array}$ & $\begin{array}{c}0 \\
(0)\end{array}$ & $\begin{array}{c}13 \\
(19.4)\end{array}$ & $\begin{array}{c}25 \\
(37.3)\end{array}$ & $\begin{array}{c}29 \\
(43.3)\end{array}$ & 4.23 & .760 & .23 \\
\hline 7 & Provision of adequate ICT facilities & $\begin{array}{c}0 \\
(0)\end{array}$ & $\begin{array}{c}0 \\
(0)\end{array}$ & $\begin{array}{c}6 \\
(9.0)\end{array}$ & $\begin{array}{c}30 \\
(44.8) \\
\end{array}$ & $\begin{array}{c}31 \\
(46.3)\end{array}$ & 4.37 & .647 & .86 \\
\hline 8 & $\begin{array}{l}\text { Organise workshops and seminars } \\
\text { for WTE lecturers on adopting } \\
\text { PoBL in skill acquisition }\end{array}$ & $\begin{array}{c}2 \\
(3.0)\end{array}$ & $\begin{array}{c}5 \\
(7.5)\end{array}$ & $\begin{array}{c}14 \\
(20.9)\end{array}$ & $\begin{array}{c}26 \\
(38.8)\end{array}$ & $\begin{array}{c}20 \\
(29.9)\end{array}$ & 3.85 & 1.03 & .78 \\
\hline 9 & $\begin{array}{l}\text { Engage WTE students in activities } \\
\text { that enhance effective } \\
\text { communication, collaboration, } \\
\text { creativity and critical thinking } \\
\text { skills } \\
\end{array}$ & $\begin{array}{c}1 \\
(1.5)\end{array}$ & $\begin{array}{c}3 \\
(4.5)\end{array}$ & $\begin{array}{c}12 \\
(17.9)\end{array}$ & $\begin{array}{c}29 \\
(43.3)\end{array}$ & $\begin{array}{c}22 \\
(32.9)\end{array}$ & 4.01 & .912 & .91 \\
\hline 10 & $\begin{array}{c}\text { Encourage group collaboration } \\
\text { among WTE students }\end{array}$ & $\begin{array}{c}6 \\
(9.0) \\
\end{array}$ & $\begin{array}{c}8 \\
(11.9) \\
\end{array}$ & $\begin{array}{c}5 \\
(7.5) \\
\end{array}$ & $\begin{array}{c}27 \\
(40.3) \\
\end{array}$ & $\begin{array}{c}21 \\
(31.3) \\
\end{array}$ & 3.73 & 1.27 & .20 \\
\hline
\end{tabular}

RQ3 What strategies could be employed in enhancing WTE students' employability skills through PoBL at COET in Nigeria?

Data in table 3 shows that all the 10 items have their mean values ranging from 3.65 to 4.37 which revealed that the mean values of each of the 10 items was above the cut-off point of 3.50, which indicated that the respondents agreed to all the 10 instructional approaches adopted in acquiring WTE skills at COET in Nigeria. Also results from table 3 revealed that the standard deviation of the 10 items ranges from 0.64-1.27 indicating that the respondents are not far in their mean responses from one another. Data in table 3 equally show that the P-values of all the 11 items exceeded 0.05 level of significance, indicating that no significant difference existed between the mean responses of the respondents on strategies that can be employed in enhancing employability skills of WTE students at COET in Nigeria. Therefore, the null hypotheses of no significant difference were upheld for all the 10 strategies.

\subsection{Qualitative Findings}

Qualitative findings for this study are presented in table and chart. Extracts from the interview conducted are presented in table 4 while percentage of responses are illustrated in figure 1 . The following codes were used for representation EI=Employability skill incorporation, EE1=Generic skills, EE2 = Core skills, EE3= Personal attributes, EA1 $=21^{\text {st }}$ Century Learning Approach, EA2= Traditional Learning Approach, ES1=Curriculum Review, ES2 $=$ Adopt PoBL, ES3= ICT Equipment, ES4= Constructive Investigation, ES5= Workshop for lecturers. 
Table 4. Interview Extracts

\begin{tabular}{|c|c|c|c|}
\hline Question & Responses & Themes & Coding \\
\hline $\begin{array}{l}\text { Kindly explain if employability } \\
\text { skills are incorporated in WTE } \\
\text { curriculum }\end{array}$ & $\begin{array}{l}\text { - Somehow, they are embedded since curriculum } \\
\text { shows some woodworking skills students are } \\
\text { expected to acquire } \\
\text { Well not exactly, but some technical skills of } \\
\text { - } \quad \text { woodworking are captured in the curriculum } \\
\text { Not really, even though the curriculum shows } \\
\text { some skills in furniture and cabinet making to } \\
\text { be taught to students }\end{array}$ & Employability skills & EI \\
\hline $\begin{array}{l}\text { What elements of employability } \\
\text { skills do you think are } \\
\text { incorporated into WTE } \\
\text { curriculum }\end{array}$ & $\begin{array}{l}\text { - Some elements of, furniture construction, } \\
\text { carpentry, upholstery } \\
\text { Workshop environment safety rules, cabinet } \\
\text { construction, some elements of wood machine } \\
\text { practice } \\
\text { Skills in the use of wood to produce wooden } \\
\text { articles, skills in using wood hand tools and } \\
\text { machine }\end{array}$ & $\begin{array}{ll}\text { - } & \text { Generic Skills } \\
\text { - } & \text { Core skills } \\
& \text { Personal } \\
& \text { Attributes }\end{array}$ & EE1, EE2, EE3 \\
\hline $\begin{array}{lr}\text { Could you please explain } \\
\text { instructional } & \text { approaches } \\
\text { adopted in acquiring WTE skills }\end{array}$ & $\begin{array}{l}\text { - Students are taught using project methods, } \\
\text { lecture, demonstration } \\
\text { Mostly lecture and demonstration are used in } \\
\text { teaching students some basic skills in } \\
\text { woodworking. } \\
\text { Sometimes project are used as method of } \\
\text { teaching wood skills, while in some situation, } \\
\text { lecturer demonstrate to students and give them } \\
\text { assignments to produce or construct a wooden } \\
\text { item }\end{array}$ & $\begin{array}{ll}\text { - } & \text { Traditional } \\
\text { - } & \text { learning approach } \\
& 21^{\text {st }} \text { century } \\
\text { learning }\end{array}$ & EA1, EA2 \\
\hline $\begin{array}{l}\text { How do you think students } \\
\text { employability skills can be } \\
\text { enhanced through project based } \\
\text { learning }\end{array}$ & $\begin{array}{l}\text { - I think if the curriculum of WTE can be } \\
\text { revisited to align with the industry skill needs } \\
\text { and also using an active learning technique like } \\
\text { the problem based learning, project based } \\
\text { learning and inquiry based learning, can help in } \\
\text { improving the skills of the students so they can } \\
\text { be employable } \\
\text { in my view I believe if project based learning } \\
\text { can be used as a method in teaching } \\
\text { woodworking skill, students' employability } \\
\text { skills can be enhanced, and in addition if } \\
\text { lecturers use approaches that can lead students } \\
\text { to improve in their communication, innovative } \\
\text { and critical thinking skills. } \\
\text { Hmm, it will be good if lecturers involved in } \\
\text { teaching WTE be trained on how to apply PoBL } \\
\text { in acquiring skills so that they can effectively } \\
\text { use it in teaching students on acquiring skills. } \\
\text { Also, provision of ICT facilities for students } \\
\text { skill acquisition in enhancing students } \\
\text { employability skills is good. }\end{array}$ & $\begin{array}{ll}\text { - } & \text { Curriculum } \\
\text { - } & \text { Review } \\
\text { - } & \text { PoBL Adoption } \\
\text { - } & \text { Constructive } \\
& \text { investigation } \\
\text { - } & \text { Workshop for } \\
& \text { lecturers }\end{array}$ & \\
\hline
\end{tabular}

Themes generated from the interview as presented in table 4 based on the question asked about employability skills incorporated into WTE curriculum, figure 1 revealed $57 \%$ of the participants perceived employability skills not incorporated into WTE curriculum, while 29\% considered employability as incorporated into WTE curriculum. Similarly, themes generated from the interview on elements of employability skills incorporated into WTE curriculum revealed from figure 1 that $57 \%$ of the participants opined that generic skills are not incorporated into WTE curriculum while $29 \%$ are silent. Further, $57 \%$ of the participants expressed that core skills are incorporated into WTE curriculum while $53 \%$ perceived personal attributes as an element of employability not incorporated into WTE curriculum. Findings from the interview on themes generated on the instructional approaches adopted in acquiring WTE skills revealed from figure 1 that $71 \%$ of the participants perceived $21^{\text {st }}$ century learning not adopted in WTE instruction while $64 \%$ perceived traditional learning as the instructional approach adopted in WTE. However, themes generated from the interview on strategies for enhancing WTE students' employability skills through PoBL revealed from figure 1 that $71 \%$ of the participants opined review of WTE curriculum to incorporate $\mathrm{PoBL}$ as a strategy for enhancing employability skill of WTE students through PoBL. 
Additionally, results from figure 4 revealed $86 \%$ of the participants perceived adoption of PoBL in WTE instruction as a strategy for enhancing WTE students' employability skill through PoBL. Furthermore, it was revealed from the themes generated from the interview as presented in figure 1 that $100 \%$ of the participants expressed provision of ICT equipment for student skill acquisition as a strategy for enhancing WTE students' employability skills through PoBL. It was also revealed from the interview as presented in figure 1 that $71 \%$ of the interviewee considered engaging students in constructive investigation as a strategy for enhancing WTE students' employability skills through PoBL. On the other hand, figure 1 shows $57 \%$ of the interviewed participants perceived organising workshop for WTE lecturers on adoption of PoBL in skill acquisition as a strategy for enhancing employability skills of WTE students through PoBL.

\section{Discussion}

Findings from both quantitative and qualitative results revealed that most elements of employability skills are not incorporated into WTE curriculum. It was also revealed from both findings that some technical skills are the elements of employability skills incorporated in WTE curriculum. These findings are in line with Ismail and Mohammed (2015) who stated that the curriculum of TVET (WTE inclusive) in Nigeria emphasizes more on technical kills, with less emphasis on the other elements of employability skills, they further stated that there is every need for TVET curriculum at tertiary level institutions in Nigeria to have a paradigm shift from providing students not only with technical skills, but also with non-technical skills. Similarly, Attaochu (2013) observed that WTE curriculum in Nigerian COET paid less emphasis on acquiring skills that could make the students employable and this resulted in graduating WTE students without the employability skills needed at the work place.

Furthermore, findings from the quantitative and qualitative results showed that virtually all the instructional approaches adopted in acquiring WTE skills at Nigerian COET are traditional or teacher centred, indicating that $21^{\text {st }}$ century learning approaches are not incorporated into WTE teaching and learning for students' skill acquisition. This is in line with (Hassan \& Ogbuanya, 2017) who asserted that the teaching and learning methods adopted in acquiring WTE skills in Nigerian COET are conventional usually with lecture and demonstration method which do not give students adequate opportunities to actively involve in the learning process to acquire the necessary skills needed at the work place. Accordingly, Akor et al. (2018); Oloyede, Ajimotokan, and Faruk (2017) observed that lecture, demonstration, project work are the most predominant teaching methods in Nigerian tertiary institutions (COET inclusive). The authors further stated that these methods of instruction are teacher centred and do not give students enough privilege to acquire appropriate skills.

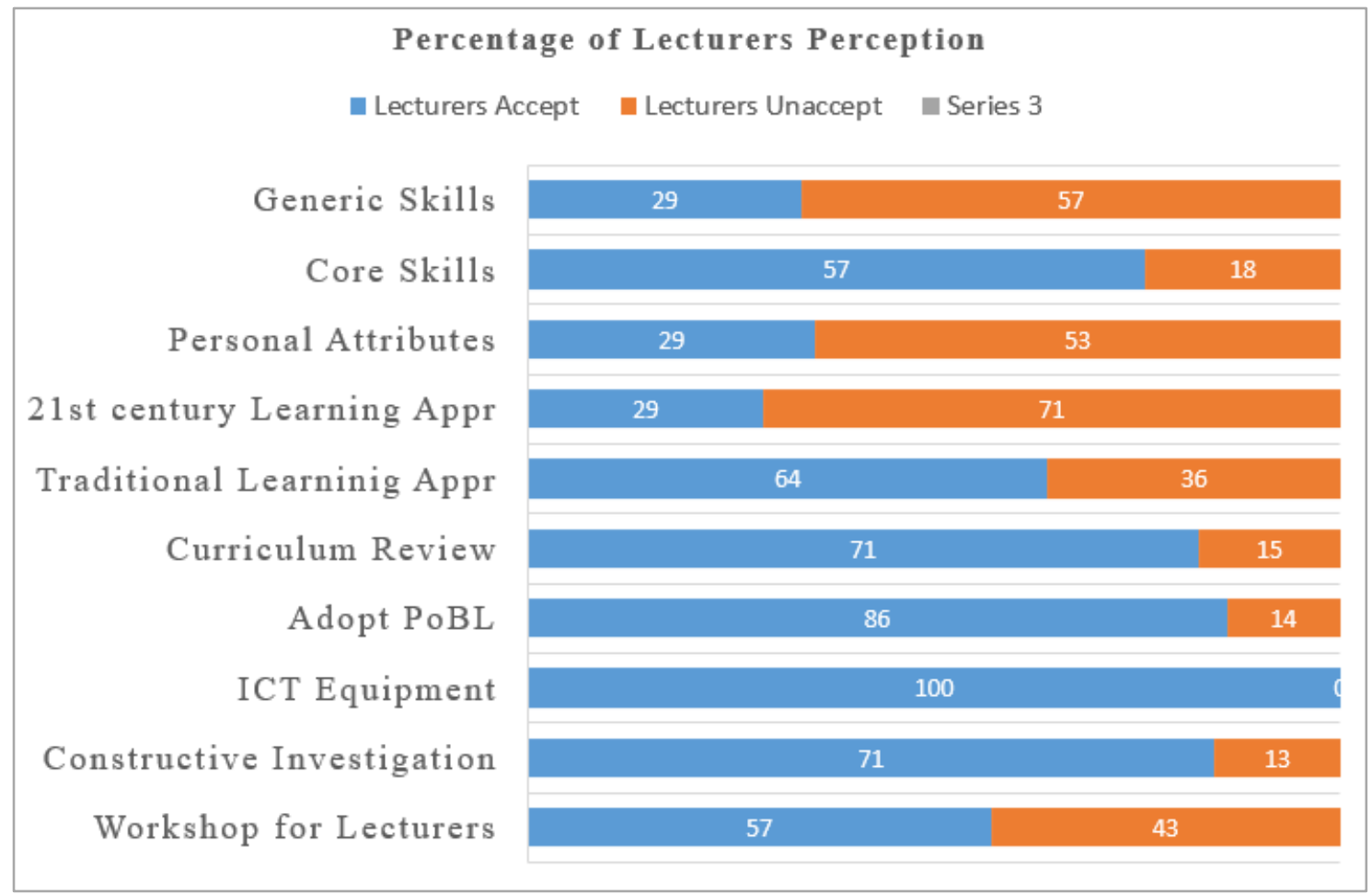

Figure 1. Chart showing percentage of Responses from interview 
On strategies that can be employed to enhance WTE students' employability skills through PoBL, findings from both quantitative and qualitative revealed that through alignment of WTE curriculum to industry needs and incorporating PoBL in WTE curriculum and instructional processes as well as organising workshops for WTE lecturers on application of PoBL in skill acquisition and engaging WTE students in constructive investigation that can help enhance their critical thinking, communication and creativity skills, WTE students employability skills can be enhanced. This finding is in line with Anane (2013) who stated that, in order for students' skills to be improved using PoBL, an educational program curriculum should link education to skills needed by industries or employers and to develop creativity and innovation in students to be competent individuals with the required employability skills for employment. Additionally, Božić (2016) posited that engagement in activities that involve utilizing information and communication technology through PoBL develops students' competency of finding information using various sources and offers students the competency to communicate effectively. Moreover, Fioravanti et al. (2018)stated that for students to effectively develop skills needed for employment, instructors need to be trained on the processes of applying PoBL in students' skills acquisition.

\section{Conclusion}

One of the main objectives of WTE in Nigerian COET is to equip students with skills that can make them employable. However, most WTE students lacked the essential employability skills for success in the work place after graduation. The curriculum and instructional approaches that are supposed to be indices for effective employability skills acquisition of WTE students could not aid in achieving this due certain defects. Therefore, this study was carried out to identify employability skills elements in WTE curriculum and instructional approaches employed in acquiring WTE skills in Nigerian COET. The study also determines effective strategies for enhancing employability skills of WTE students at COET in Nigeria. In conclusion, responses and views of lecturers from the COETs determined effective strategies for enhancing employability skills of WTE students' employability through PoBL at COET in Nigeria.

\section{REFERENCES}

[1] Akor, T. S., Noordin, M. K., Subari, K., Jambari, H., Nasir, A. N. M., \& Pairan, M. R. Prospects of Problem And Project Based Learning Blend For Fourth Industrial Revolution Ready Electronics Engineering Programmes In Nigerian Universities.
[2] Aliyu, A. M. (2016). Strategies for Improving Practical Projects in Woodwork in Colleges of Education (Technical) in North-Western States of Nigeria.

[3] Anane, C. A. (2013). Competency based training: Quality delivery for technical and vocational education and training (TVET) institutions. Educational research international, 2(2), 117-127.

[4] Attaochu, E. U. (2013). Quality assurance of teachers in the implementation of the curriculum of technical and vocational education in colleges of education (technical) in North Cenrtal Nigeria. International Journal of Adult Vocational Education and Technology (IJAVET), 4(2), 34-43.

[5] Bender, W. N. (2012). Project-based learning: Differentiating instruction for the 21st century: Corwin Press.

[6] Božić, M. (2016). Competence development in a project and problem based learning professional practice module in engineering education based on ill-structured problem solving action research and its implications for sustainability education.

[7] Colwell, J. (2010). Professional Skills for the New Economy: Their Place in Graduate Education in Engineering and Engineering Technology. Paper presented at the American Society for Engineering Education.

[8] Du, X., \& Kolmos, A. (2006). Process competencies in a problem and project based learning environment. Paper presented at the 35th SEFI annual conference: Engineering education and active students.

[9] Fioravanti, M. L., Sena, B., Paschoal, L. N., Silva, L. R., Allian, A. P., Nakagawa, E. Y., Barbosa, E. F. (2018). Integrating Project Based Learning and Project Management for Software Engineering Teaching: An Experience Report. Paper presented at the Proceedings of the 49th ACM Technical Symposium on Computer Science Education.

[10] Hassan, A., \& Ogbuanya, T. (2017). effect of challenge-based and activity-based learning approaches on technical college student's achievements and retention in woodwork technology. AU-eJournal of Interdisciplinary Research (ISSN: 2408-1906), 2(2).

[11] Ismail, S., \& Mohammed, D. S. (2015). Employability Skills in TVET Curriculum in Nigeria Federal Universities of Technology. Procedia-Social and Behavioral Sciences, 204, 73-80.

[12] Johnson, B., \& Ulseth, R. (2014). Professional competency attainment in a project based learning curriculum: A comparison of project based learning to traditional engineering education. Paper presented at the 2014 IEEE Frontiers in Education Conference (FIE) Proceedings.

[13] Lowden, K., Hall, S., Elliot, D., \& Lewin, J. (2011). Employers' perceptions of the employability skills of new graduates. London: Edge Foundation.

[14] Muhammad, I. U. (2016). Utilization of Models as Alternatives to Tests for Measuring Skills in Furniture-Making in Technical Colleges. 
[15] Nasir, A. N. M., Ali, D. F., Noordin, M. K. B., \& Nordin, M. S. B. (2011). Technical skills and non-technical skills: predefinition concept. Paper presented at the Proceedings of the IETEC'11 Conference, Kuala Lumpur, Malaysia.

[16] Noordin, M. K. (2014). Project-based Learning Framework for Non-technical Skills. Universiti Teknologi Malaysia,

[17] Oloyede, A., Ajimotokan, H., \& Faruk, N. (2017). Embracing the future of engineering education in Nigeria: teaching and learning challenges. Nigerian Journal of Technology, 36(4), 991-1001.

[18] Ravitz, J., Hixson, N., English, M., \& Mergendoller, J. (2012). Using project based learning to teach 21st century skills: Findings from a statewide intitiative (pp. 10). Vancouver, BC.

[19] Tam, A., \& Trzmiel, B. (2018). Transversal Skills as a Missing Link Between School and Work: Experiences from the Asia-Pacific Region. In Transitions to Post-School Life (pp. 35-49): Springer.

[20] Tongco, M. D. C. (2007). Purposive sampling as a tool for informant selection. Ethnobotany Research and applications, 5, 147-158.

[21] Udofia, A., Ekpo, A., Nsa, S., \& Akpan, E. (2012). Instructional variables and students' acquisition of employable skills in vocational education in Nigerian technical colleges. Mediterranean Journal of Social Sciences, 3(14), 118-127.

[22] United Nations Educational, S., \& Organization, C. (2010). Education for All Global Monitoring Report 2010: Reaching the Marginalized.

[23] Wickramasinghe, V., \& Perera, L. (2010). Graduates', university lecturers' and employers' perceptions towards employability skills. Education+ Training, 52(3), 226-244. 